\title{
MICROPROPAGATION OF STEVIA PLANT FROM NODAL SEGMENTS
}

\author{
M. A. Karim, R. Jannat, M. S. Rahman and M. S. Haque ${ }^{1}$ \\ Department of Crop Botany, Bangladesh Agricultural University \\ Mymensingh-2202, Bangladesh
}

\begin{abstract}
The experiment was conducted to develop and establish a reproducible protocol for plantlet regeneration in Stevia. Nodal cutting explants were cultured in Murashige and Skoog (MS) medium supplemented with different concentrations and combinations of a-Napthaleneacetic acid (NAA) and 6-Benzylamino purine (BAP). The combination of NAA at $1.0 \mathrm{mgl}^{-1}$ and BAP at $1.0 \mathrm{mgl}^{-1}$ resulted in the highest percentage $(100 \%)$ of callus initiation. The maximum shoot regeneration and development of shoot was observed at the same combination. The developed shoots from nodal cuttings, upon transfer to the MS medium containing indole butyric acid (IBA) at $0.1 \mathrm{mgl}^{-1}$ resulted in best rooting within 8 days.
\end{abstract}

Key words : Micropropagation, plantlet regeneration, Stevia, Nodal segment

\section{INTRODUCTION}

Stevia rebaudiana Bert. belonging to the family Compositae, is one of the most valuable tropical medicinal plant. Stevia is originally a South Amarican wild plant (Katayma et al., 1976). But it could be found in semi-arid habitat ranging from grassland to scrub forest to mountain terrain. Stevia grows to about $50-65 \mathrm{~cm}$ tall, with sessile, oppositely arranged lanceolate to oblanceolate leaves, serrated towards apex. It is one of 154 members of the genus Stevia, which produces sweet steviol glycosides like stevioside, rebaudioside A, rebaudioside $C$ and dulcoside A. Pure extract of stevioside is non-caloric and 300 times sweeter than suger (Bhole, 2004) unlike many low-caloric sweetners, stevioside is stable at high temperatures and over a range of $\mathrm{pH}$ values from 3 to 9 (Kinghorn and Soejarto, 1985). It is also non-caloric, non-fermentable and does not darken upon cooking (Crammer and Ikan, 1986). It is suited for both diabetic patients, as well as for obese persons intending to lose weight by avoiding sugar supplement in the diet. No allergic reactions seem to exist (Geuns, 2003). Stevia is used as a table top sweetener, in soft drink, fruit juices, ice creams, yoghurts, sherbets, pastries, pies, baking, jams, sauces, pickles, jellies, desserts, chewing gum, candies, confectionary goods, sea- foods, vegetables, etc.

The conventional methods of cultivation or propagation of Stevia is time consuming, unpredictable, unreliable and less productive. Therefore, there is a crucial need to develop methods for rapid multiplication of Stevia. Seed germination of Stevia is often poor and less productive. Due to instability of plantlet produced through stem cutting,

\footnotetext{
${ }^{1}$ Department of Biotechnology, Bangladesh Agricultural University, Mymensingh-2202, Bangladesh
} 
micropropagation method may overcome many of the limitations associated with conventional method and can be used for rapid multiplication. On the above mentioned perspective, the present study was undertaken to develop and establish a reproducible protocol for plantlet regeneration and to determine the suitable concentration.

\section{MATERIALS AND METHODS}

An experiment on in vitro callus induction and subsequent plantlet regeneration of Stevia was conducted at the Laboratory of the Department of Biotechnology, Bangladesh Agricultural University, Mymensingh in order to fulfill the objectives set in this research programme. Murashige and Skoog (MS) medium was used. Proper sterilization of MS medium, test tubes, pipette, petridishes, beakers, scalpels, forceps, needles and other glasswares and growth chamber were made. Incubation chamber was properly maintained. The nodal explants were cut into small pieces (about $0.5-0.6 \mathrm{~cm}$ long) and then treated with $2 \%$ savlon with constant shaking for 5-6 minutes and washed thoroughly with distilled water. Then the explants were taken under Laminer Air Flow Cabinet. The surface sterilization of the explants was done with $0.5 \%$ mercuric chloride solution for 5 minutes under aseptic condition followed by washing 5-6 times with sterilized distilled water.

Explants were cultured on MS medium supplemented with different concentrations and combinations of BAP at $\left(0,1,2.5\right.$ and $\left.5 \mathrm{mgl}^{-1}\right)$ and NAA at $\left(0,1,2.5\right.$ and $\left.5 \mathrm{mgl}^{-1}\right)$ for callus initiation and proliferation. Calli from nodes were subcultured on the same medium. The calli were again cultured on MS medium supplemented with different concentrations and combinations of BAP at $\left(0,1,2.5,5\right.$ and $\left.10 \mathrm{mgl}^{-1}\right)$ and NAA at $\left(0 \& 1 \mathrm{mgl}^{-1}\right)$ for shoot proliferation. Media supplemented with different concentrations of IBA $(0,0.1,0.5$ and 1.0 $\left.\mathrm{mgl}^{-1}\right)$ and NAA $\left(0,0.1,0.5\right.$ and $\left.1.0 \mathrm{mgl}^{-1}\right)$ were used for root induction. Culture vessels were incubated at $25 \pm 1^{0} \mathrm{C}$ with $16 \mathrm{~h}$ photoperiod with light intensity of approximately 2000 lux.

\section{RESULTS AND DISCUSSION}

\section{Callus induction}

Induction of callus is an important factor for enhancing the rate of cell division resulting more fresh weight of callus. The cultured nodal segments were found to be able to produce profuse calli. The results of callus production and multiplication are presented in Table 1. Node explants upon culture on MS medium containing BAP plus NAA started callus initiation after 10 days (Fig. 1, A). The greatest amount of callus was obtained from node explants on the medium containing $1.0 \mathrm{mgl}^{-1} \mathrm{NAA}$ plus $1.0 \mathrm{mgl}^{-1} \mathrm{BAP}$ and callus weight was also highest $(0.78 \mathrm{~g})$. The other combinations showed poor performance and no callus was initiated on medium without growth regulators. Himanshu et al. (2006) observed best calli formation in MS medium containing $10 \mu \mathrm{M}$ a-Napthaleneacetic acid plus $8.8 \mu \mathrm{M}$ benzyl adenine. The friable and loose calli (brownish colour) did not show 
shoot regeneration. Compact calli were considered as best for its high regeneration capacity. The compact calli were usually brownish to light green in colour (Fig. 1, B).

Table 1. Effects of different concentrations and combinations of NAA and BAP on callus initiation

\begin{tabular}{|c|c|c|c|c|c|c|}
\hline \multicolumn{2}{|c|}{$\begin{array}{l}\text { Growth } \\
\text { regulators } \\
\left(\mathrm{mg} \mathrm{l}^{-1}\right)\end{array}$} & \multirow[t]{2}{*}{$\begin{array}{c}\% \text { calli } \\
\text { induction }\end{array}$} & \multirow[t]{2}{*}{$\begin{array}{c}\text { Days to } \\
\text { calli } \\
\text { induction }\end{array}$} & \multirow[t]{2}{*}{ Colour of calli } & \multirow[t]{2}{*}{$\begin{array}{c}\text { Callus } \\
\text { morphologies }\end{array}$} & \multirow{2}{*}{$\begin{array}{c}\text { weight }(\mathrm{g}) \text { of } \\
\text { individual } \\
\text { callus after } 45 \\
\text { days }\end{array}$} \\
\hline NAA & BAP & & & & & \\
\hline 0.0 & 0.0 & 0.00 & 0.00 & - & - & 0.00 \\
\hline 0.0 & 1.0 & 0.00 & 0.00 & - & - & 0.00 \\
\hline 0.0 & 2.5 & 40.00 & 16.00 & Brownish & Friable & 0.42 \\
\hline 0.0 & 5.0 & 40.00 & 17.00 & Brownish to Blackish & Friable & 0.43 \\
\hline 1.0 & 0.0 & 95.00 & 14.00 & Brownish to Light green & Compact & 0.75 \\
\hline 1.0 & 1.0 & 100.00 & 13.00 & Brownish to Light green & Compact & 0.78 \\
\hline 1.0 & 2.5 & 65.00 & 15.00 & Brownish to Light green & Compact & 0.50 \\
\hline 1.0 & 5.0 & 55.00 & 16.00 & Brownish to Light green & Compact & 0.47 \\
\hline 2.5 & 0.0 & 80.00 & 14.00 & Brownish to Light green & Compact & 0.74 \\
\hline 2.5 & 1.0 & 90.00 & 14.00 & Brownish to Light green & Compact & 0.78 \\
\hline 2.5 & 2.5 & 60.00 & 16.00 & Brownish to Light green & Compact & 0.52 \\
\hline 2.5 & 5.0 & 50.00 & 17.00 & Brownish & Friable & 0.51 \\
\hline 5.0 & 0.0 & 60.00 & 16.00 & Brownish to Light green & Compact & 0.50 \\
\hline 5.0 & 1.0 & 65.00 & 16.00 & Brownish to Light green & Compact & 0.51 \\
\hline 5.0 & 2.5 & 55.00 & 17.00 & Brownish & Friable & 0.51 \\
\hline 5.0 & 5.0 & 50.00 & 17.00 & Brownish & Friable & 0.47 \\
\hline LSD & & 11.41 & 0.895 & - & - & 0.014 \\
\hline
\end{tabular}

\section{Plantlet regeneration}

Cultured node explants produced calli on MS medium containing BAP and NAA. The calli began to increase in size and proliferation was started for new shoot at 13 days after subculture. The combination of NAA at $1.0 \mathrm{mgl}^{-1}$ and BAP at $1.0 \mathrm{mgl}^{-1}$ showed better performance and besides these the other concentrations and combinations showed poor performance. Node explants induced the highest percentage $(87.50 \%)$ of shoots at minimum number of days (13) with NAA at $1.0 \mathrm{mgl}^{-1}$ and $1.0 \mathrm{mgl}^{-1}$ (Fig. 1, D). Single concentration of BAP $\left(10.0 \mathrm{mgl}^{-1}\right)$ acted as a growth promoter and produced higher number of shoots (12) callus $^{-1}$ with shorter shoot length $(6.63 \mathrm{~cm})$ but when BAP was combined with NAA $\left(1.0 \mathrm{mgl}^{-1}+10.0 \mathrm{mgl}^{-1}\right)$ the number of shoots callus ${ }^{-1}$ was reduced to (2.25) and shoot length increased $(11.18 \mathrm{~cm})$ (Table 2). Higher number of healthy shoots (46.9) obtained from nodal segments with $5.0 \mathrm{mgl}^{-1} \mathrm{IBA}$ and $2.0 \mathrm{mgl}^{-1}$ NAA (Maharik and Gengaihi, 2003). 
After inoculation of 28 days, shoots from node explants were isolated from the culture vessels and transferred to MS medium containing different levels of auxin (IBA) or (NAA) for rooting. The highest number of roots $(95 \%)$ was induced on medium containing $0.1 \mathrm{mgl}^{-1}$ IBA within the minimum number of days (8.00) (Fig. 1, E). Similar result was also obtained from $1.0 \mathrm{mgl}^{-1} \mathrm{NAA}$ (Table 3). But maximum number of roots (6.25) was obtained from node explants with $1.0 \mathrm{mgl}^{-1}$ NAA. Himanshu et al. (2006) showed significant enhancement in the induction of rooting from $16.1 \mu \mathrm{M}+10.7 \mu \mathrm{M}$ BA. The lowest concentration of IBA $\left(0.1 \mathrm{mgl}^{-1}\right)$ and the highest concentration of NAA $\left(1.0 \mathrm{mgl}^{-1}\right)$ gave similar results. So, it can be suggested that application of $0.1 \mathrm{mgl}^{-1} \mathrm{IBA}$ is much better than others. After rooting both shoots and roots continued to grow until complete well developed plantlets were established.

Table 2. Effects of different concentrations and combinations of BAP and NAA on shoot regeneration

\begin{tabular}{|c|c|c|c|c|c|}
\hline \multicolumn{2}{|c|}{$\begin{array}{l}\text { Concentrations of growth } \\
\text { regulators }\left(\mathrm{mg} \mathrm{l}^{-1}\right)\end{array}$} & \multirow{2}{*}{$\begin{array}{l}\text { Percentage of } \\
\text { shoot } \\
\text { regeneration }\end{array}$} & \multirow[t]{2}{*}{$\begin{array}{l}\text { Days to shoot } \\
\text { induction }\end{array}$} & \multirow[t]{2}{*}{$\begin{array}{c}\text { Number of } \\
\text { shoots/callus }\end{array}$} & \multirow{2}{*}{$\begin{array}{l}\text { Shoot length } \\
(\mathrm{cm}) \text { after } 28 \\
\text { days }\end{array}$} \\
\hline NAA & BAP & & & & \\
\hline 0.0 & 0.0 & $0.00 \mathrm{~d}$ & $0.00 c$ & $0.00 \mathrm{f}$ & $0.00 \mathrm{f}$ \\
\hline 0.0 & 2.5 & $20.00 \mathrm{c}$ & $15.00 \mathrm{a}$ & $2.00 \mathrm{e}$ & $7.50 \mathrm{~d}$ \\
\hline 0.0 & 5.0 & $85.00 \mathrm{a}$ & $13.25 b$ & $8.00 \mathrm{~b}$ & 7.30de \\
\hline 0.0 & 10.0 & $87.50 \mathrm{a}$ & $13.25 b$ & $12.00 \mathrm{a}$ & $6.63 \mathrm{e}$ \\
\hline 1.0 & 1.0 & $87.50 \mathrm{a}$ & $13.00 \mathrm{~b}$ & $5.00 c$ & $10.50 \mathrm{ab}$ \\
\hline 1.0 & 2.5 & $75.00 \mathrm{~b}$ & $14.75 a$ & $4.50 \mathrm{c}$ & $9.70 \mathrm{c}$ \\
\hline 1.0 & 5.0 & $72.50 \mathrm{~b}$ & $15.00 \mathrm{a}$ & $3.50 \mathrm{~d}$ & $10.38 b c$ \\
\hline 1.0 & 10.0 & $70.00 \mathrm{~b}$ & $15.25 a$ & $2.25 \mathrm{e}$ & 11.18a \\
\hline LSD & & 6.141 & 0.7886 & 0.7736 & 0.6969 \\
\hline
\end{tabular}

Mean followed by different letter(s) in each column are significantly different at $5 \%$ level according to DMRT

Table 3. Effects of IBA and NAA on rooting

\begin{tabular}{cc|c|c|c}
\hline $\begin{array}{c}\text { Concentrations of growth } \\
\text { regulators }\left(\mathrm{mgl}^{-1}\right)\end{array}$ & $\begin{array}{c}\text { Percentage of root } \\
\text { induction }\end{array}$ & Days to root induction & $\begin{array}{c}\text { Number of } \\
\text { roots / plantlet }\end{array}$ \\
\hline IBA & 0.0 & $30.00 \mathrm{~d}$ & $11.25 \mathrm{c}$ & $2.50 \mathrm{~cd}$ \\
& 0.1 & $95.00 \mathrm{a}$ & $8.00 \mathrm{~d}$ & $5.00 \mathrm{~b}$ \\
& 0.5 & $50.00 \mathrm{bc}$ & $13.50 \mathrm{~b}$ & $2.50 \mathrm{~cd}$ \\
& 1.0 & $45.00 \mathrm{~cd}$ & $14.50 \mathrm{ab}$ & $1.50 \mathrm{~d}$ \\
\hline NAA & 0.0 & $30.00 \mathrm{~d}$ & $11.25 \mathrm{c}$ & $2.50 \mathrm{~cd}$ \\
& 0.1 & $60.00 \mathrm{bc}$ & $14.50 \mathrm{ab}$ & $2.50 \mathrm{~cd}$ \\
& 0.5 & $65.00 \mathrm{~b}$ & $14.75 \mathrm{a}$ & $3.00 \mathrm{c}$ \\
\hline LSD & 1.0 & $95.00 \mathrm{a}$ & $8.00 \mathrm{~d}$ & $6.25 \mathrm{a}$ \\
\hline
\end{tabular}

Mean followed by different letter(s) in each column are significantly different at $5 \%$ level according to DMRT 

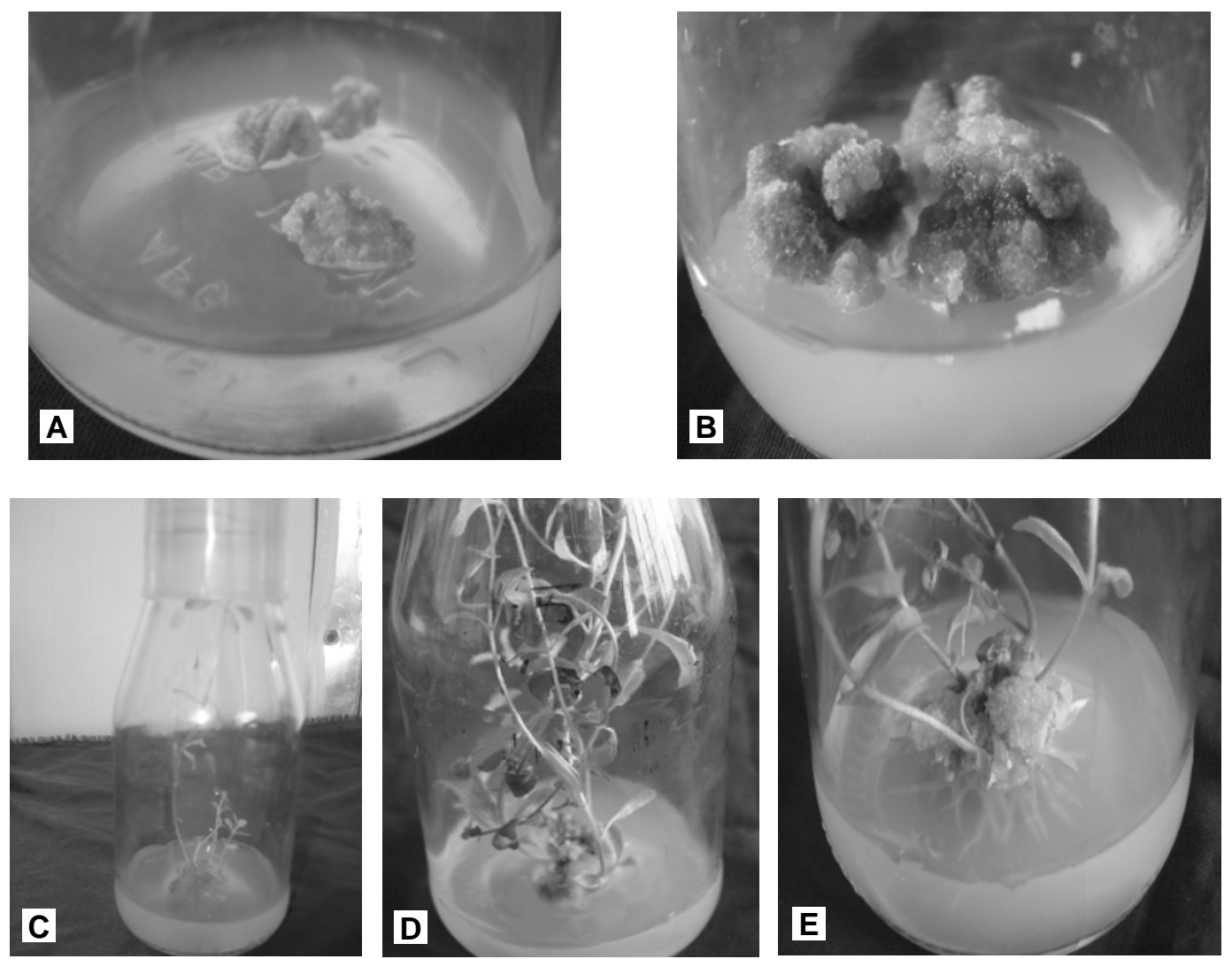

Fig. 1. Plantlet regeneration from nodal explants of Stevia

A) Callus from nodes at 16 days after inoculation;

B) Callus from nodes at 45 days after inoculation;

C) Shoot from callus at 14 days after inoculation;

D) Shoot from callus at 28 days after inoculation; and

E) Roots produced from shoots at 14 days after subculture.

Finally, it may be concluded that maximum calli induction, shoot regeneration were achieved with the combination of NAA at $1.0 \mathrm{mgl}^{-1}$ and BAP at $1.0 \mathrm{mgl}^{-1}$. Shoots from node explants produced maximum number of roots containing $0.1 \mathrm{mgl}^{-1} \mathrm{IBA}$ in the medium. A protocol for the micropropagation Stevia has been developed in this study.

\section{REFERENCES}

Bhosle, S. 2004. Commercial cultivation of Stevia rebaudiana. Agrobios Newsl., 3(2): 43-45.

Crammer, B. and Ikan, R. 1986. Sweet glycosides from the Stevia plant. Chem. Britain. 22: 915-916.

Geuns, J. M. 2003. Stevioside. Phytochemistry, 64(5): 913-21 
Himanshu, D., Kumar, M. and Haider, Z.A. 2006. In vitro morphogenesis of Stevia: the naturally occuring sweet plant- a fast and efficient method to propagate Stevia by tissue culture. J. Res. Birsa Agril. Univ., 18(1): 1-9.

Katayama, O., Sumida, T., Hayashi, H. and Mltsuhashi, H. 1976. The practical application of Stevia and research and development data (English translation). I.S.U. Company, Japan. 747.

Kinghorn, A. D. and Soejarto, D. D. 1985. Current status of stevioside as a sweetening agent for human use. Wagner, H., Hikino, H. and Farnsworth, N. R. (eds.). Economic and Medical Plant Research. Academic Press, London.

Maharik, N. T. and El-Gengaihi, S. E. 2003. Micropropagation of Stevia rebaudiana Bertoni. Egyptian J. Hort., 30(1/2): 125-134. 